\title{
Publisher Correction: Single-cell gene expression reveals a landscape of regulatory T cell phenotypes shaped by the TCR
}

David Zemmour, Rapolas Zilionis, Evgeny Kiner, Allon M Klein, Diane Mathis and Christophe Benoist (D) Correction to: Nature Immunology https://doi.org/10.1038/s41590-018-0051-0 (2018); published online 12 February 2018.

In the version of this article initially published, the Supplementary Note was missing. The Supplementary Note has now been provided online and is cited in the Methods section of the article. The error has been corrected in the HTML and PDF version of the article.

Published online: 3 May 2018

https://doi.org/10.1038/s41590-018-0104-4

\section{Publisher Correction: Natural variation in the parameters of innate immune cells is preferentially driven by genetic factors}

Etienne Patin (D), Milena Hasan, Jacob Bergstedt (D), Vincent Rouilly, Valentina Libri, Alejandra Urrutia, Cécile Alanio (D), Petar Scepanovic, Christian Hammer, Friederike Jönsson, Benoît Beitz, Hélène Quach, Yoong Wearn Lim, Julie Hunkapiller, Magge Zepeda, Cherie Green, Barbara Piasecka, Claire Leloup, Lars Rogge, François Huetz, Isabelle Peguillet, Olivier Lantz, Magnus Fontes, James P. Di Santo, Stéphanie Thomas, Jacques Fellay (D), Darragh Duffy, Lluís Quintana-Murci (iD, Matthew L. Albert (D) and The Milieu Intérieur Consortium

Correction to: Nature Immunology https://doi.org/10.1038/s41590-018-0049-7 (2018); published online 23 February 2018.

In the version of this article initially published, the name of one author was incorrect (James P. Santo). The correct name is James P. Di Santo. The error has been corrected in the HTML and PDF versions of the article. 